Meta

Journal des traducteurs

Translators' Journal

\title{
Enhancing Translation Students' Theoretical Knowledge and Skills Through Web-enriched Learning Resources: Case Study in Distance Learning
}

\section{Karnedi}

Volume 60, numéro 2, août 2015

$60^{\mathrm{e}}$ anniversaire. Les horizons de la traduction : retour vers le futur

$60^{\text {th }}$ Anniversary. Translation's Horizons: Back to the Future

60mo aniversario. Los horizontes de la traducción: regreso al futuro

URI : https://id.erudit.org/iderudit/1032900ar

DOI : https://doi.org/10.7202/1032900ar

Aller au sommaire du numéro

Éditeur(s)

Les Presses de l'Université de Montréal

ISSN

0026-0452 (imprimé)

1492-1421 (numérique)

Découvrir la revue

Citer ce document

Karnedi (2015). Enhancing Translation Students' Theoretical Knowledge and Skills Through Web-enriched Learning Resources: Case Study in Distance

Learning. Meta, 60(2), 349-349. https://doi.org/10.7202/1032900ar 


\title{
Enhancing Translation Students' Theoretical Knowledge and Skills Through Web-enriched Learning Resources: Case Study in Distance Learning
}

\author{
KARNEDI \\ Indonesia Open University, Banten, Indonesia \\ karnedi@ecampus.ut.ac.id
}

Translation learning modules, as offered by most universities worldwide, are traditionally print-based. However, to cater for translation students with open learning resources, other universities have also conducted considerable research and development relating to technology-based learning resources. Within the context of distance learning, this paper reports on a series of stages of designing, developing and evaluating an online translation learning resource. To achieve the objectives, two models of research are adopted - Research and Development model and Web-Based Instructional Design/WBID model. In terms of methodology, the development of the web-enriched translation learning resources goes through several major stages: (1) analysis stage aiming to study the outcomes, context, learners, instructional content, instructional design, and the use of educational technology; (2) evaluation planning stage examining related aspects (i.e., effectiveness, efficiency, appeal, usability); (3) concurrent design stage involving the design, development, formative evaluation, and initial implementation; (4) full implementation stage. This research adopts mixed methods - qualitative and quantitative methods. As for data collection associated with the programme evaluation, a number of techniques are used (i.e., in-depth interviews with the experts of content area, instructional designers, media experts, and surveys (online questionnaire), observation involving the users (i.e., students and tutors), assessment instruments, as well as a documentation study of the existing translation self-directed learning modules. A critical analysis of these issues is followed by a crucial discussion. The paper concludes with an assertive view that a combination between the web-enriched learning resources and online tutorial packages specially designed for translation teaching and learning would not only create greater access for the translation students to translation learning resources in order to improve their theoretical knowledge and skills but will also produce a higher quality of translation learning resources.

Karnedi is a Senior Lecturer in Translation at the Indonesia Open University (Universitas Terbuka). He holds a PhD in Translation Studies/TS from the University of Indonesia/UI (2011), and was a visiting scholar at the School of Arts, Languages and Cultures, University of Manchester, UK (2008). He also completed a Master's Degree in Media Technology for TEFL from the University of Newcastle, UK (1995), and a Bachelor's Degree in Linguistics from UI (1990). He has published some coursebooks on translation and English language skills specially designed for distance learning, a bilingual children's dictionary and a bilingual glossary of ODL terminology. His research papers in TS, online teaching and learning have been published in some international journals. 